\title{
A new species of Proceratophrys Miranda-Ribeiro (Amphibia: Anura: Cycloramphidae) from the Chapada Diamantina, State of Bahia, northeastern Brazil
}

\author{
MARCELO FELGUEIRAS NAPOLI ${ }^{1,2,6}$, CARLOS ALBERTO GONÇALVES CRUZ ${ }^{3}$, RAFAEL OLIVEIRA DE \\ $\mathrm{ABREU}^{4} \&$ MARIA LUCIA DEL-GRANDE 5 \\ ${ }^{\prime}$ Museu de Zoologia, Departamento de Zoologia, Instituto de Biologia, Universidade Federal da Bahia, Campus Universitário, Rua \\ Barão de Jeremoabo, Ondina, 40170-115 Salvador, Bahia, Brazil \\ ${ }^{2}$ Associate Researcher, Departamento de Vertebrados, Museu Nacional, Universidade Federal do Rio de Janeiro \\ ${ }^{3}$ Universidade Federal do Rio de Janeiro, Museu Nacional, Departamento de Vertebrados, Quinta da Boa Vista, São Cristóvão, \\ 20940-040 Rio de Janeiro, Rio de Janeiro,Brazil.E-mail: cagcruz@uol.com.br \\ ${ }^{4}$ Programa de Pós-Graduação em Diversidade Animal, Instituto de Biologia, Universidade Federal da Bahia, Campus Universitário, \\ Rua Barão de Jeremoabo, Ondina, 40170-115 Salvador, Bahia, Brazil. E-mail: rafaeloabreu@yahoo.com.br \\ ${ }^{5}$ Universidade Estadual do Sudoeste da Bahia, Departamento de Ciências Naturais, Estrada do Bem Querer, km 4, $45031-900$ Vitória \\ da Conquista, Bahia, Brazil. E-mail: delgrandeml@gmail.com \\ ${ }^{6}$ Corresponding author: napoli@ufba.br
}

\begin{abstract}
We describe a new species of Proceratophrys, allied to $P$. schirchi, from the northern sector of the Espinhaço mountain range, within a semiarid region in central State of Bahia known as Chapada Diamantina. The new species inhabits seasonal semi-deciduous forests (usually known as dry forests) that cover the mountainous relief of the Serra de Jacobina, a regional designation of the Espinhaço mountain range in northeastern Brazil. Proceratophrys minuta sp. nov. most resembles $P$. schirchi by combination of small palpebral appendages, general external morphology, and by its restriction to Atlantic Forest remnants. It is diagnosed from all congeners by the combination of small body size (snout-vent length, males 20.4-25.2 mm, females 28.3-31.9 mm), absence of rostral appendage, short palpebral appendages with the central prominent, dorsum adorned with sinuous longitudinal ridges outlining a spear-shaped ornamentation like a hastate-shaped leaf (with flaring pointed lobes at eyes and spear point at urostile), and other six morphological characteristics. We also describe the tadpole of $P$. minuta sp. nov., and compare its color and external morphology with other tadpoles of Proceratophrys described in the literature.
\end{abstract}

Key words: Alsodinae, Proceratophrys minuta sp. nov., Proceratophrys schirchi, taxonomy, Serra de Jacobina

\section{Resumo}

Descrevemos uma nova espécie de Proceratophrys, semelhante a P. schirchi, proveniente do setor norte da Serra do Espinhaço, em região semiárida no centro do Estado da Bahia conhecida como Chapada Diamantina. A nova espécie habita florestas estacionais semideciduais (usualmente conhecidas como florestas secas) que cobrem o relevo montanhoso da Serra de Jacobina, designação regional da Serra do Espinhaço no nordeste do Brasil. Proceratophrys minuta sp. nov. mais se assemelha a $P$. schirchi pela combinação de apêndices palpebrais pequenos, aspecto geral da morfologia externa e por sua restrição a remanescentes de Floresta Atlântica. É diagnosticado de todos os congêneres pela combinação do tamanho corpóreo pequeno (comprimento rostro-cloacal, machos 20,4-25,2 mm, fêmeas 28,3-31,9 mm), ausência de apêndice rostral, apêndices palpebrais curtos e com o central proeminente, dorso adornado com cristas longitudinais sinuosas delineando ornamentação lanceolada semelhante à folha hastada (com lobos divergentes e pontiagudos junto aos olhos e ponta da lança junto ao uróstilo) e outras seis características morfológicas. Também descrevemos o girino de $P$. minuta sp. nov. e comparamos sua cor e morfologia externa com outros girinos de Proceratophrys descritos na literatura. 


\section{Introduction}

The Neotropical genus Proceratophrys Miranda-Ribeiro currently comprises 24 species distributed in Brazil, northeastern Argentina, and Paraguay (Martins \& Giaretta 2011, Ávila et al. 2011, Frost 2011). These species are usually ordered within three main phenetic groups, mostly characterized by the presence or the absence of a single and long palpebral (upper eyelid) appendage and postocular swellings.

Species with a single and long uni-cuspidate palpebral appendage are combined within the species complexes of P. boiei and P. appendiculata (Izecksohn et al. 1998; Prado \& Pombal 2008, Cruz \& Napoli 2010), and species lacking this feature are grouped in the P. bigibbosa and P. cristiceps groups. Two species are not promptly associated to one of these groups: $P$. rondonae Prado and Pombal holds a single and short multi-cuspidate palpebral appendage, but was considered within the long-horned toads by Prado and Pombal (2008); P. schirchi (MirandaRibeiro) was not assigned to a species group by its singular external morphology, including short palpebral appendages (Prado \& Pombal 2008), a decision followed by Cruz and Napoli (2010) and Martins and Giaretta (2011).

The Proceratophrys bigibbosa species group is characterized by a blunt and short snout, presence of postocular swellings, and large marginal tubercles on eyelids (Kwet \& Faivovich 2001), and currently comprises four species: P. avelinoi Mercadal de Barrio and Barrio, P. bigibbosa (Peters), P. brauni Kwet and Faivovich, and $P$. palustris Giaretta and Sazima. This species group occurs in southern and southeastern Brazil and adjacent countries (Giaretta et al. 2000, Kwet \& Faivovich 2001).

The Proceratophrys cristiceps species group is characterized by the absence of palpebral appendages and postocular swellings (other shared characters are not evident), and is mainly distributed over open and seasonally dry environments (Giaretta et al. 2000); currently it comprises seven species: P. concavitympanum Giaretta, Bernarde and Kokubum, P. cristiceps (Müller), P. cururu Eterovick and Sazima, P. goyana (Miranda-Ribeiro), $P$. moratoi (Jim and Caramaschi), P. strussmannae Ávila, Kawashita-Ribeiro and Morais, and P. vielliardi Martins and Giaretta.

The Proceratophrys boiei and P. appendiculata species complexes are characterized by the presence of a single and long uni-cuspidate palpebral appendage, the latter with a triangular rostral appendage that is absent in the former. Three species are formally included in the P. boiei complex: P. boiei (Wied-Neuwied), P. paviotii Cruz, Prado and Izecksohn, and $P$. renalis (Miranda-Ribeiro); eight species are formally included in the $P$. appendiculata complex: P. appendiculata (Günther), P. laticeps Izecksohn and Peixoto, P. melanopogon (Miranda-Ribeiro), $P$. moehringi Weygoldt and Peixoto, P. phyllostomus Izecksohn, Cruz and Peixoto, P. sanctaritae Cruz and Napoli, $P$. subguttata Izecksohn, Cruz and Peixoto, and P. tupinamba Prado and Pombal. These species complexes are distributed mainly along the coastal Atlantic Rainforest.

Surveys of anurans in the northern sector of the Espinhaço mountain range in the State of Bahia, Brazil, namely the Chapada Diamantina ecoregion, led us to find a new species of Proceratophrys allied to P. schirchi, which is described herein.

\section{Material and methods}

Museum abbreviations of specimens used in the descriptions or examined for comparisons are: MNRJ (Museu Nacional, Rio de Janeiro, Brazil), UESB (Coleção de Anfíbios, Universidade Estadual do Sudoeste da Bahia, Vitória da Conquista, Estado da Bahia, Brazil), and UFBA (Museu de Zoologia da Universidade Federal da Bahia, Salvador, Bahia, Brazil).

Measurements of adult specimens follow Prado and Pombal (2008) and are in millimeters: SVL (snout-vent length), HL (head length), HW (head width), ED (eye diameter), UEW (upper eyelid width), IOD (interorbital distance), IND (internarial distance), END (eye to nostril distance), THL (thigh length), TL (tibia length), and FL (foot + tarsus length). Measurements were taken with a vernier caliper. Drawings of the holotype were made using a Leica-Wild MZ6 stereomicroscope with a drawing tube. Webbing formula notation follows Savage and Heyer (1997). The nomenclature used to describe the external morphology of the genus Proceratophrys follows Prado and Pombal (2008). Diagnosis and comparisons with other species were based on examined specimens (appendix 1) and on the following literature: Proceratophrys bigibbosa species group: Kwet and Faivovich (2001); 
Proceratophrys boiei species group: Prado and Pombal (2008), Cruz and Napoli (2010); P. cristiceps species group: Ávila et al. (2011), Martins and Giaretta (2011).

The number of specimens in each lot of tadpoles follows the collection registration number, in parentheses. The analysis and description of the external morphology of tadpoles of Proceratophrys minuta is based on nine specimens: UFBA 10756 (7), 10757 (1), 10758 (1), in stages 31-38 (Gosner 1960); other eight individuals, UFBA 10750 (8) in earlier (25-27) and later (40-41) stages were considered for comparisons. We measured 17 morphometric characters, recorded in millimeters. Five measurements follow Altig and McDiarmmid (1999): TL (total length), BL (body length), TAL (tail length), MTH (maximum tail height), and TMH (tail muscle height). Five measurements follow Mercês and Juncá (2010): DFH (dorsal fin height), VFH (ventral fin height), ED (eye diameter), ODW (oral disc width), and SSD (spiracle-snout distance). IOD (interorbital distance) follows Nascimento et al. (2010). The six other measurements are: BH (maximum body height), BW (maximum body width), IND (internarial distance, distance between internal borders of nares), ESD (eye-tip of snout distance, distance from anterior corner of eye to tip of snout), END (eye-nostril distance, distance from the anterior corner of eye to posterior border of nostril), and NSD (nostril-tip of snout distance, distance from anterior border of nostril to tip of snout). An ocular micrometer in a Zeiss stereomicroscope was used for measuring all variables. Nomenclature of morphological characteristics follow Altig and Johnston (1986) and Altig and McDiarmid (1999). Illustration of the tadpole is based on the individual stage 35 (UFBA 10758), employing the labial tooth row formula proposed by Altig (1970). All individuals were fixed in 4\% formalin and are deposited in the Museu de Zoologia da Universidade Federal da Bahia.

\section{Description of new species}

\section{Proceratophrys minuta sp. nov.}

Figures 1-4

Holotype. UFBA 6721 , adult male, collected at the Riacho do Dandá $\left(11^{\circ} 26^{\prime} \mathrm{S}, 40^{\circ} 33^{\prime} \mathrm{W}\right.$, ca. $800 \mathrm{~m}$ above sea level), Parque Estadual das Sete Passagens (an environmental State protected area), Municipality of Miguel Calmon, State of Bahia, Brazil, on 22 November 2006, by Rafael Oliveira de Abreu and Heverton Cardona.

Paratypes. Brazil, State of Bahia: Municipality of Miguel Calmon, Parque Estadual das Sete Passagens (11 $26^{\circ} \mathrm{S}, 40^{\circ} 33^{\prime} \mathrm{W}$, ca. $800 \mathrm{~m}$ a.s.l.)—MNRJ 75410 (ex-UFBA 6229, adult female), 75411 (ex-UFBA 6230, adult male), collected on 22-25 July 2006, by A. Xavier, M.B. Santos, and R. Burger; UFBA 6287, adult male, collected on 12-16 October 2006, by A.L. Xavier, D. Cruz, M. Camardelli, P.M. Fonseca, and R.O. Abreu; UFBA 6289 (adult male), 6290 (adult female), collected on 12-16 October 2006, by A.L. Xavier, D. Cruz, M. Camardelli, P.M. Fonseca, and R.O. Abreu; UFBA 6356-6358 (adult males), 6353-6355 (adult females), MNRJ 75417 (ex-UFBA 6351), UFBA 6349, 6350, 6352 (juveniles), collected on 23 July 2006, by A.L. Xavier, D. Cruz, M. Camardelli, P.M. Fonseca, and R.O. Abreu; MNRJ 75412-75416 (adult males, ex-UFBA 6718, 6722, 6723, 6726, 6728 [stained and cleared], respectively), UFBA 6716, 6720, 6725, 6727 (adult males), 6724 (adult female), 6717, 6719 (juveniles), collected on 18-23 November 2006, by A.L. Xavier, D. Cruz, M. Camardelli, P.M. Fonseca, R.O. Abreu, and W. Fahning; UFBA 7156, 7158 (adult males), 7155, 7157 (juveniles), collected on 20 January 2007, by A. Xavier, D. Cruz, R.A. Abreu, N. Menezes, and T. Jordão. Municipality of Palmeiras, Morro do Pai Inácio $\left(12^{\circ} 27^{\prime} 49^{\prime \prime S}, 41^{\circ} 28^{\prime} 26^{\prime \prime W}\right.$, ca. $840 \mathrm{~m}$ a.s.l.) -UFBA 10755, adult male, collected on 01 May 2006, by M.L. DelGrande; UFBA 10751-10754 (ex-UESB 387-390), adult males, collected on 28 September 2006, by M.L. DelGrande.

Diagnosis. In the genus Proceratophrys by lacking nuptial pads on thumb, body without enlarged glands, fingers not webbed, supernumerary tubercles present on hands and feet, dorsal surfaces of fingers and toes wrinkled, and dorsum adorned with sinuous longitudinal ridges outlining a spear-shaped ornamentation like a hastate-shaped leaf, with flaring pointed lobes at eyes and spear point at urostile. Proceratophrys minuta is related to P. schirchi (Miranda-Ribeiro) by the presence of outer metacarpal tubercle single or partially grooved, and a short palpebral appendage with marginal tubercles, the largest tubercle in the middle more projected than lateral tubercles. The new species is diagnosed from its congeners by the following combination of characteristics: (1) small size (adult males SVL 20.4-25.2 mm, adult females 28.3-31.9 mm); (2) absence of rostral appendage; (3) a 
short palpebral appendage with marginal tubercles, the largest tubercle in the middle more projected than lateral tubercles; (4) snout rounded from above, vertical or slightly oblique in profile; (5) canthus rostralis well-marked, curved; (6) dorsum adorned with sinuous longitudinal ridges outlining a spear-shaped ornamentation like a hastateshaped leaf, with flaring pointed lobes at eyes and spear point at urostile; (7) dorsum with a pair of parallel thin rows of warts extending from interorbital to scapular region; (8) distinct row of warts transversally on head, interrupted at the center, and extending to the border of each eyelid; and (9) outer metacarpal tubercle single or partially grooved.

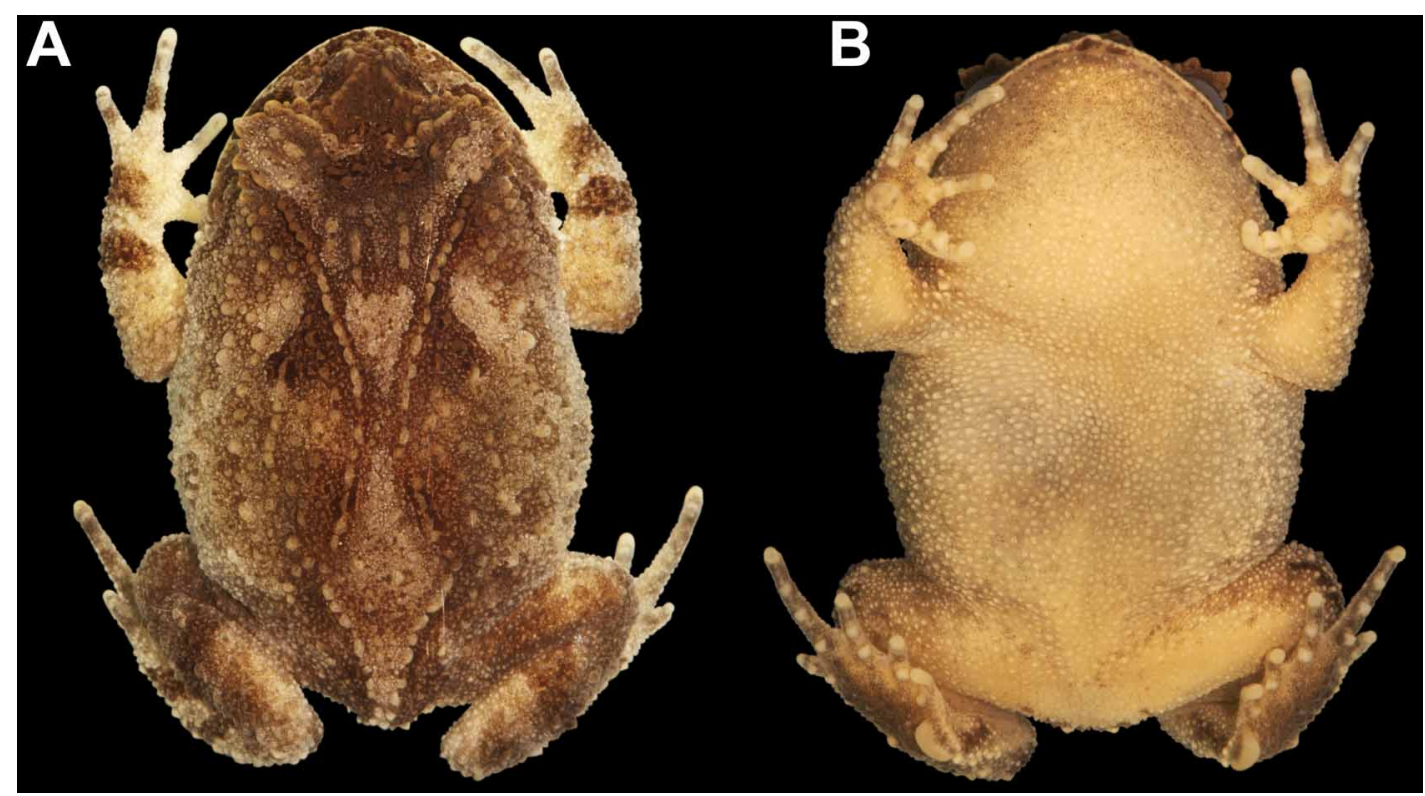

FIGURE 1. Proceratophrys minuta sp. nov. A, dorsal and (B) ventral views of holotype, UFBA 6721, adult male, SVL 23.9 mm. Photo Rafael O. Abreu.

Comparisons with other species. Proceratophrys minuta is promptly diagnosed from all species of the $P$. bigibbosa group (P. avelinoi, P. bigibbosa, P. brauni, and P. palustris) by the absence of postocular swellings (present in those species), from all species of the $P$. boiei group (P. appendiculata, P. boiei, P. laticeps, $P$. melanopogon, P. moehringi, P. paviotii, P. phyllostomus, . renalis, $P$. sanctaritae, $P$. subguttata, and $P$. tupinamba) by the absence of a single long uni-cuspidate palpebral appendage (present in those species), and from $P$. rondonae by the smaller snout-vent length ( $P$. minuta males $20.0-25.2 \mathrm{~mm}$, females $28.3-31.9 \mathrm{~mm}$; $P$. rondonae males 52.6-63.4 mm, females 37.7-72.8 mm); P. minuta is promptly distinguished from all species of the $P$. cristiceps group ( $P$. concavitympanum, $P$. cristiceps, $P$. cururu, $P$. goyana, $P$. moratoi, $P$. strussmannae, and $P$. vielliardi) and from $P$. schirchi by the smaller snout vent-length $20.4-25.2 \mathrm{~mm}$ in males $(P$. cristiceps species group, SVL in males: $P$. concavitympanum 39.6-51.8 mm, P. cristiceps 40.6-49.1 mm, P. cururu 36.5-43.1 mm, P. goyana 28.0-55.5 mm, P. moratoi 26.4-30.0 mm, P. strussmannae 41.1-47.3 mm, and P. vielliardi 39.1-41.9 mm; $P$. schirchi 31.6-40.4 mm); P. minuta is also diagnosed from all species of the $P$. cristiceps group by the outer metacarpal tubercle single or partially grooved and a short palpebral appendage with marginal tubercles, the largest tubercle in the middle more projected than lateral tubercles (outer metacarpal tubercle completely divided, and absence of palpebral appendages in those species); from $P$. moratoi and $P$. vielliardi the new species also differs by the dorsum adorned with sinuous longitudinal ridges outlining a spear-shaped ornamentation like a hastate-shaped leaf, with flaring pointed lobes at eyes and spear point at urostile (absent in those species); $P$. minuta is diagnosed from $P$. concavitympanum, $P$. cristiceps, $P$. cururu, $P$. goyana, $P$. strussmannae, and $P$. schirchi by dorsum with a pair of parallel thin rows of warts extending from interorbital to scapular region (thick rows of warts in those species); furthermore, $P$. minuta is diagnosed from $P$. schirchi by the absence of a rostral appendage (short rostral appendage present in that species).

Description of holotype. Head wider than long, head length $87 \%$ of head width; snout rounded in dorsal view, slightly oblique in profile (figs 1, 2A, B); nares elliptical, prominent, and external to the canthal crest, internarial distance $77 \%$ of eye to nostril distance; canthal crests well marked, curved, and prominent; no preocular crests; 
loreal region oblique; distinct row of spatulated warts from posterior corner of eye to angle of jaw; eye directed anterolateraly, small, 29\% of head length; six short palpebral appendages, central appendage prominent; tympanum not distinct; row of warts transversally on head, interrupted at the center, extending to the border of each eyelid; a pair of parallel thin rows of warts extending from interorbital region to scapular region; vocal sac slightly expanded externally; tongue cordiform, free posteriorly; choanae large, well separated one from the other; vomerine teeth in two short transverse series lying between choanae; vocal slits large; no frontoparietal crest. Arms moderately robust (fig. 1); finger lengths I $\approx$ II IV < III (figs 1, 2C); nuptial asperities absent; interdigital webbing absent; inner metacarpal tubercle large, elliptical; outer metacarpal tubercle twice the size of the inner, elliptical, and partially grooved; scarce small rounded supernumerary tubercles; subarticular tubercles large, nearly rounded, and grooved anteriorly and posteriorly. Legs moderately robust (fig. 1), thigh length longer than tibia length, the sum of thigh and tibia lengths $78 \%$ of snout-vent length; dorsal surface of tibia with three oblique parallel rows of enlarged warts; foot length $57 \%$ of snout-vent length; toes adorned with marginal spinulose tubercles (fig. 2D); toe lengths I < II < V < III < IV; webbing formula I 1-2 II 1-3 III 2-4 IV 4-2 V; inner metatarsal tubercle large, spatulated; outer metatarsal tubercle small, rounded; numerous small rounded supernumerary tubercles; subarticular tubercles large, nearly rounded, and grooved anteriorly and posteriorly. Dorsum adorned with sinuous longitudinal ridges outlining a spear-shaped ornamentation like a hastate-shaped leaf, with flaring pointed lobes at eyes and spear point at urostile (fig. 1). Dorsal surfaces and flanks with warts of different sizes and shapes, set in rows or scattered; ventral surfaces, except hands and feet, covered by numerous small, circular, uniform warts; skin and warts of dorsal and ventral surfaces covered by minuscule asperities.

Color in life. Based on color photographs of two paratypes: an adult male not identified among paratypes UFBA 6230, 6256-6258, and an adult female, UFBA 6290 (fig. 3A-D). Dorsal ground color faded tan brown, maculated with variegated browns, mainly with color tons of cream, reddish and grayish browns, looking like dead leaves. Longitudinal ridges of the spear-shaped ornamentation on dorsum dark brown to reddish brown, not contrasting with dorsal ground color. Warts on dorsum cream, reddish brown or dark brown; palpebral appendages reddish brown. Interior surface of the spear-shaped ornamentation on dorsum not contrasting with the rest of the dorsal surface in one specimen (fig. 3A), and grayish brown in the other, in which it contrasts from the general tan background color (fig. 3B, C). Upper eyelids light brown to grayish brown, connected by a light brown or reddish brown interorbital stripe. An oblique row of cream color warts is noticeable from the angle of jaw to the upper arm. Upper lip cream color. Canthus rostralis delimited from below by a dark brown irregular stripe, from anterior corner of eye to nostril. Lorus with grayish brown to dark brown background color, maculated by a dark brown band from the anterior corner of eye to upper lip, followed by two other dark brown bands, the latter from the posterior corner of eye to near the upper arm. Tip of snout dark brown. Two to three transverse dark brown bars on forearm, shank, and foot. Ventral ground color of throat, chest, belly, arms, legs, hands, and feet tan color, with warts and tubercles cream (fig. 3D). Pupil black; iris copper brown, its lower region gray color ornamented by black reticulations, marginally delimited by an irregular black aureole.

Color in preservative. Based on the type-series. Follows the color in life, but with less vivid colors (fig. 1). The background of dorsal surface varied from light brown to dark brown. Specimens with light brown background color (UFBA 6287, 6289, 6290, 6349-6352, 6354, 6355, 6723, 6725, 7157) evidenced a spear-shaped ornamentation on dorsum bordered along its external sides by a wave-shaped dark brown band, somewhat fragmented into three main dark brown triangular marks. Yet, in these specimens the dark brown stripes on arms and legs are well distinct from the background. These features are still noticeable, but less evident, in specimens of darker background color (UFBA 6357, 6358, 6716-6722, 6724, 6726, 6727), and not visible in specimens of darkest brown background color (UFBA 6353, 6356, 7156). Dorsal warts dark brown or cream color. Anterior and posterior surfaces of thigh with background color cream to homogeneous brown, immaculate or maculated by irregular dark brown marks and/or dark brown pin dots. Throat, chest, belly, ventral surfaces of arms and legs with cream background color, varying from almost immaculate (UFBA 6287, 6289, 6290, 6352, 6355, 6358, 6717, 6719-6721, 6723) to intensively scattered with dark brown pin dots (UFBA 6725, 6726, 6230). Palm of hand and sole of foot dark brown; subarticular and supernumerary tubercles cream color.

Measurements of holotype (mm). SVL 23.9; HL 9.6; HW 11.0; ED 2.8; UEW 3.3; IOD 2.7; IND 1.7; END 2.2; THL 9.8; TL 8.9; FL 13.7. 

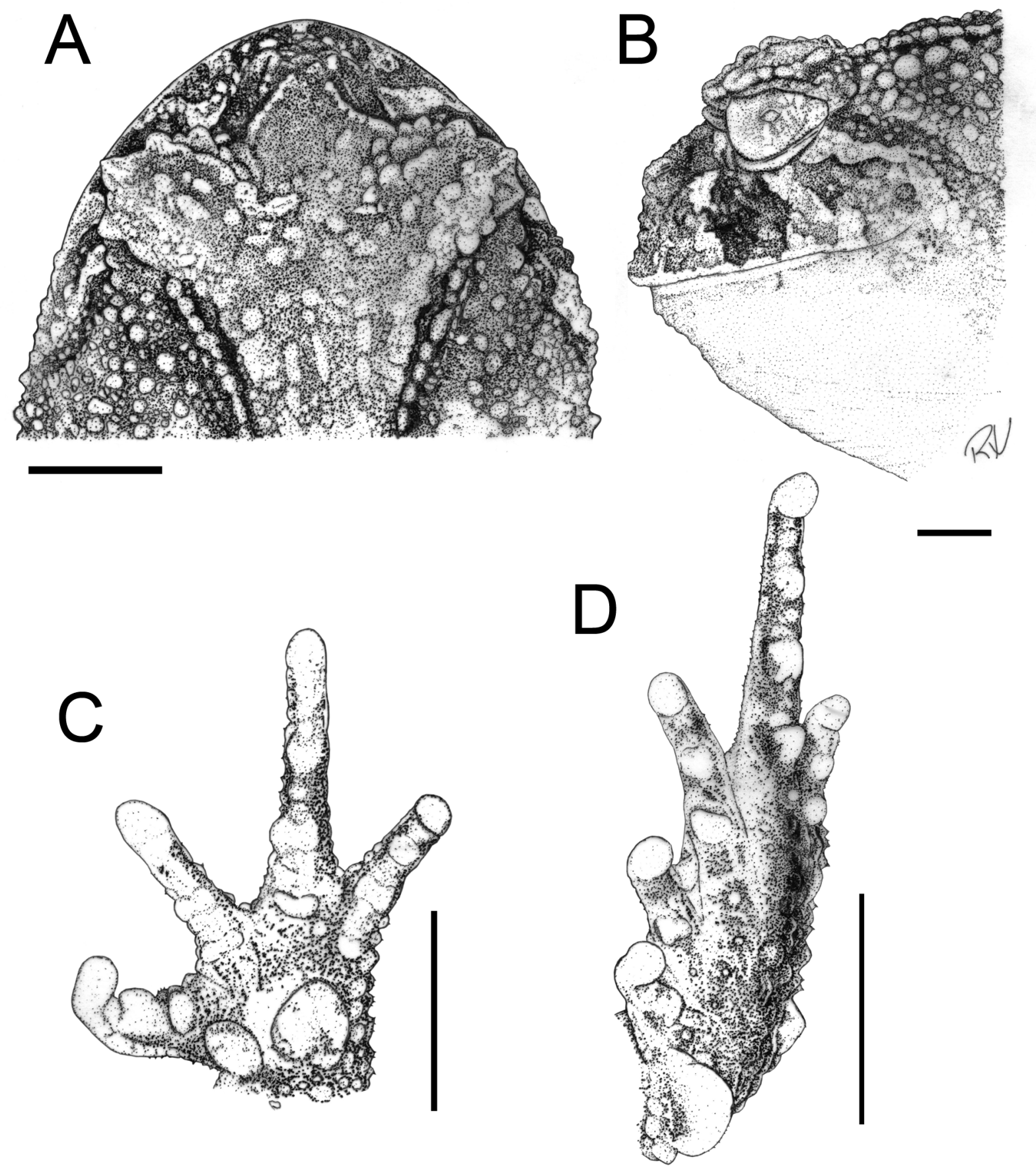

FIGURE 2. Holotype of Proceratophrys minuta sp. nov., UFBA 6721, adult male. Dorsal (A) and lateral (B) views of head; ventral views of hand (C) and foot (D). Horizontal and vertical lines equal $3.0 \mathrm{~mm}$. Line drawing Rafael O. Abreu.

Variation. Specimens are congruent with respect to the morphologic characters. Descriptive statistics of measurement variables from adult males and females are in Table 1. Variations in color patterns were already described in color in life and color in preservative items.

Etymology. The specific name, a Latin adjective (minutus = small, minute), is an allusion to the small size of the new species. 
TABLE 1. Descriptive statistics of adult males (including the holotype) and females of Proceratophrys minuta from the Parque Estadual das Sete Passagens, Municipality of Miguel Calmon, and from Morro do Pai Inácio, Municipality of Palmeiras, both in the State of Bahia, Brazil. Mean = arithmetic mean; SD = standard deviation. Measurements are in millimeters.

\begin{tabular}{lcccccccccccc}
\hline & \multicolumn{4}{c}{ Parque Estadual das Sete Passagens } & \multicolumn{3}{c}{ Females $(\mathrm{n}=6)$} & \multicolumn{3}{c}{ Morro do Pai Inácio } \\
& \multicolumn{3}{c}{ Males $(\mathrm{n}=18)$} & \multicolumn{3}{c}{ Males (n= 5) } \\
& Mean & SD & Min & Max & Mean & SD & Min & Max & Mean & SD & Min & Max \\
\hline SVL & 22.7 & 1.2 & 20.4 & 25.2 & 30.3 & 1.5 & 28.3 & 31.9 & 21.0 & 0.8 & 20.0 & 22.1 \\
HL & 9.6 & 0.4 & 9.0 & 10.4 & 12.1 & 0.6 & 11.5 & 13.0 & 8.2 & 0.6 & 7.4 & 9.1 \\
HW & 11.1 & 0.6 & 10.4 & 12.9 & 14.5 & 1.1 & 13.5 & 16.1 & 9.5 & 0.8 & 8.4 & 10.5 \\
IND & 1.7 & 0.3 & 1.4 & 2.5 & 2.3 & 0.2 & 2.0 & 2.5 & 1.6 & 0.2 & 1.5 & 1.9 \\
END & 2.1 & 0.2 & 1.5 & 2.5 & 2.7 & 0.3 & 2.5 & 3.1 & 1.8 & 0.1 & 1.7 & 1.9 \\
ED & 2.9 & 0.2 & 2.7 & 3.2 & 3.7 & 0.1 & 3.5 & 3.8 & 2.7 & 0.2 & 2.5 & 3.0 \\
UEW & 3.4 & 0.3 & 3.0 & 3.8 & 4.3 & 0.3 & 3.9 & 4.7 & 2.7 & 0.1 & 2.7 & 2.9 \\
IOD & 2.7 & 0.2 & 2.3 & 3.0 & 3.3 & 0.3 & 3.0 & 3.7 & 2.6 & 0.1 & 2.4 & 2.7 \\
THL & 9.9 & 0.5 & 8.8 & 10.5 & 12.9 & 0.7 & 12.0 & 13.7 & 8.8 & 1.0 & 7.4 & 10.0 \\
TL & 8.8 & 0.3 & 8.3 & 9.5 & 11.5 & 0.7 & 10.5 & 12.3 & 7.6 & 0.3 & 7.4 & 8.0 \\
FL & 14.0 & 0.4 & 13.2 & 15 & 18.1 & 0.9 & 17.0 & 19.2 & 11.6 & 0.4 & 11.1 & 12.1 \\
HL/SVL & 0.43 & 0.02 & 0.39 & 0.45 & 0.40 & 0.01 & 0.38 & 0.41 & 0.39 & 0.02 & 0.37 & 0.43 \\
HW/SVL & 0.49 & 0.02 & 0.46 & 0.52 & 0.48 & 0.02 & 0.46 & 0.51 & 0.45 & 0.03 & 0.42 & 0.49 \\
HW/HL & 1.16 & 0.04 & 1.10 & 1.24 & 1.20 & 0.04 & 1.14 & 1.27 & 1.15 & 0.02 & 1.13 & 1.18 \\
THL/SVL & 0.44 & 0.02 & 0.40 & 0.46 & 0.43 & 0.01 & 0.41 & 0.45 & 0.42 & 0.03 & 0.37 & 0.45 \\
TL/SVL & 0.39 & 0.02 & 0.36 & 0.42 & 0.38 & 0.01 & 0.36 & 0.39 & 0.36 & 0.01 & 0.35 & 0.37 \\
FL/SVL & 0.62 & 0.03 & 0.57 & 0.67 & 0.60 & 0.01 & 0.59 & 0.61 & 0.55 & 0.02 & 0.52 & 0.57 \\
THL+TL/SVL & 0.83 & 0.04 & 0.77 & 0.87 & 0.81 & 0.02 & 0.78 & 0.84 & 0.78 & 0.03 & 0.74 & 0.81 \\
\hline
\end{tabular}

Natural History. All specimens of Proceratophrys minuta were captured inside gallery forests, always near (1-5 m distance) forest brooks of shallow waters (2-50 cm deep) with approximately $0.5-2 \mathrm{~m}$ wide. Advertisement calls of specimens from the Parque Estadual das Sete Passagens, Municipality of Miguel Calmon, State of Bahia, Brazil, were heard from these streams, from October to November 2008. Newly metamorphosed juveniles were recorded at the edge of a stream. Tadpoles were captured on 12-16 October 2006 by Rafael O. Abreu and Milena Camardelli, inside permanent forest streams of about $30 \mathrm{~cm}$ water depth, but also in temporary shallow streams (ca. 2-10 cm deep) of shaded areas in the Campo Rupestre (open habitat) that receive water from rivers and springs located in gallery forests. Adult specimens released distress calls when manipulated by the researchers. All paratypes from Morro do Pai Inácio, Municipality of Palmeiras, State of Bahia, Brazil, were emitting advertisement calls when they were captured, always positioned on the leaf litter, and never hidden under leaves or fallen logs. At this place, advertisement calls were always heard after nightfall, from September to October 2006. A detailed study of the spatial distribution of the anuran fauna of the Parque Estadual das Sete Passagens, including $P$. minuta, can be assessed in Xavier and Napoli (2011), referred in that publication as 'Proceratophrys sp. nov., allied to $P$. schirchi'.

Tadpoles. Description of the tadpole of Proceratophrys minuta was based on nine specimens [UFBA 10756 (7), 10757 (1), 10758 (1)] in stages 31-38. Descriptive statistics is in Table 2. Total length 29.7-36.1 mm. Body wider than high, depressed, ovoid-elongated in lateral view, oval in dorsal view (fig. 3E). Body length 38.8-41.7\% total length; body height $69.2-78.8 \%$ body width, and $45.7-57.4 \%$ body length. Snout rounded in lateral and dorsal views; snout slopes gradually toward the oral disc. Eye small, its diameter $9.0-10.3 \%$ body length, positioned dorsally, laterally directed; interorbital distance $36.1-44.4 \%$ body width; eye-snout distance $27.1-31.3 \%$ body length; eye-nostril distance 7.5-10.7\% body length; nostril small, reniform, with small cutaneous extension on its inner margin, positioned dorsally midway between eyes and snout, but slightly nearer to eyes. Internarial distance 15.0-19.7\% body width. Spiracle short, sinistral, inner wall free from body, positioned laterally on the beginning of the medium third of body, posterodorsally directed. Vent tube short, with dextral opening, fused to tail fin. 

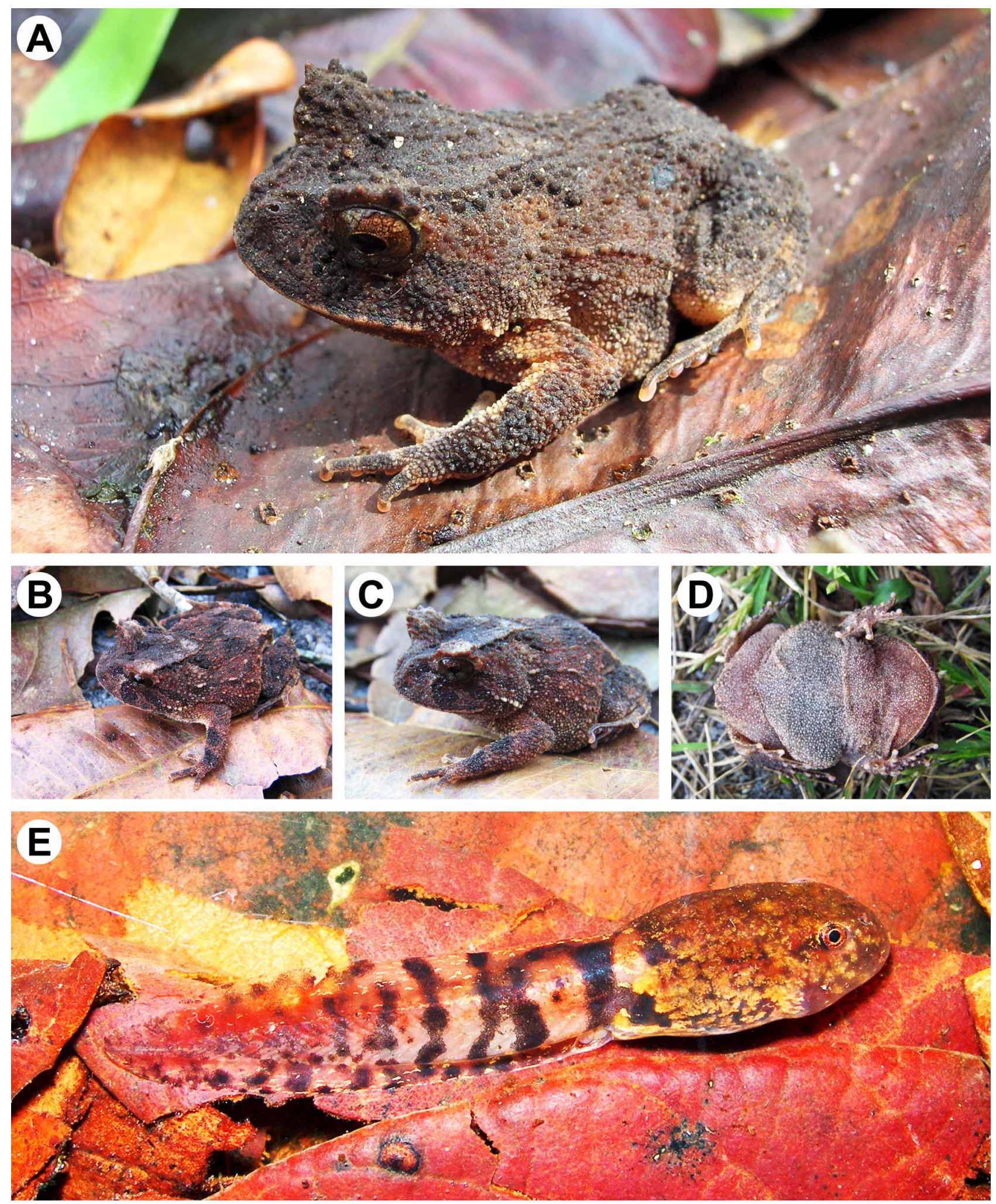

FIGURE 3. Living specimens of Proceratophrys minuta sp. nov. from Parque Estadual das Sete Passagens, Serra de Jacobina, Municipality of Miguel Calmon, State of Bahia, Brazil. A, adult male, vouchered, but not identified among paratypes UFBA 6230, 6256-6258. B-D, adult female, UFBA 6290, SVL 28.3 mm; E, tadpole, UFBA 10757, CT 33.1 mm, stage 35 (Photos by Deise Cruz and Rafael O. Abreu: A, 24 July 2006; B-D, 13 October 2006; E, 23 January 2007).

Tail length 58.3-61.2\% total length; tail as high as the body height, slightly arched. Tip of tail rounded to slightly pointed. Dorsal fin starts on junction of body to tail, 1.3-1.7 times higher than the ventral fin, both highest at the second third of the tail; ventral fin slightly less arched than the dorsal fin. Oral disk emarginated, ventrally 
positioned, its width 30-38\% body width, surrounded by a single row of conical or rounded marginal papillae, which are widely interrupted at the anterior labium. The marginal papillae are larger at the posterior labium, becoming smaller laterally towards the anterior labium. Tooth row formula 2(2)/3(1) with rows of teeth placed on ridges; rows A-1 and A-2 of equal length and P-3 shorter than the others. Labial teeth black, long, slightly curved towards oral opening. Upper and lower jaw sheaths wide, with serrated edges; upper sheath shaped as a shallow-M, lower sheath U-shaped.

Live tadpoles with dorsum densely covered by irregularly bordered golden blurs that reach the lower region of flanks, in which they became sparse, fragmented and shaped as small horizontal lines, which also occur in the venter and tail. Tail with 1-5 well marked broad and black irregular vertical bars, which are fragmented into smaller blotches towards fins and tail tip. The transparence of the skin confers to musculature a clear whitish-pink color. Venter transparent, oral region white, internal organs slightly visible. Iris orange-red, bordered internally and externally with the same golden color of dorsum, presenting a darken region that resembles a vertical bar. Limb bud with black marks. Dorsal surfaces of body, tail musculature, and dorsal fin at the end of tail with irregular areas of reddish-brown faded blurs.

Preserved tadpoles have translucent pale brown skin, clearer in tail. Dorsum with sparse dark-brown spots, the golden color became a clear bare visible brown. Black bars and blotches became dark brown. Intestine remains visible. Iris black. Tadpoles (UFBA 10750) in earlier (25-27) and later (40-41) stages are congruent with respect to general morphology and color of tadpoles in stages 31-38.

Out of 24 species of Proceratophrys, only 13 have their larvae formally described: P. boiei (Izecksohn et al.1979), P. appendiculata (Peixoto \& Cruz 1980), P. laticeps (Peixoto et al. 1981), P. schirchi (Peixoto et al. 1984, as P. precrenulata; see Caramaschi \& Velosa 1997), P. moehringi (Weygoldt \& Peixoto 1985), P. concavitympanum (Giaretta et al. 2000), P. palustris (Giaretta \& Sazima 1993), P. moratoi (Rossa-Feres \& Jim 1996), P. cururu (Eterovick \& Sazima 1998), P. avelinoi (de Sá \& Langone 2002), P. cristiceps (Vieira et al. 2007), P. renalis (Nascimento et al. 2010), and P. tupinamba (Fatorelli et al. 2010).

Live tadpoles of Proceratophrys minuta differ in color from that of $P$. avelinoi, $P$. cristiceps, $P$. concavitympanum, $P$. cururu, $P$. palustris, and $P$. moratoi mainly by the golden blurred dorsum and presence of black vertical bars in tail of the former (background color brown, maculated with dark brown or gray blotches in these species), and also from P. moehringi and P. renalis (these two species differ from the six former species mainly by the presence of dark brown transverse bands on dorsal surfaces of the tail musculature). The overall color pattern of P. minuta tadpoles resembles that of P. schirchi, P. appendiculata and P. laticeps, but differs in the pattern of bars and blotches/spots on tail. In $P$. minuta, the tail musculature is often covered in its entire vertical range by transversal black bars, which sometimes reach the dorsal fin (transversal brown bars covering only dorsal region of tail musculature in $P$. schirchi, P. appendiculata, P. boiei, and P. laticeps); P. minuta tadpoles present only the first third of ventral fin transparent, ventral fin fully transparent and maculated by small golden blotches in $P$. schirchi (Peixoto et al. 1984); tadpoles of $P$. minuta lack a small cream blotch in the middle of dorsum reported for P. appendiculata by Peixoto and Cruz (1980). The blurs that cover the dorsum and flanks of $P$. minuta are golden colored, silver in P. boiei. Proceratophrys minuta lacks pale brown reticulations on caudal musculature and fins reported for P. moehringi by Weygoldt and Peixoto (1985). The golden blurred dorsum and the presence of black vertical bars on tail musculature of $P$. minuta tadpoles differ them from that of $P$. renalis, which lack such patterns. Morphological features of tadpoles of Proceratophrys minuta are similar to that observed for the genus, with few subtle differences among species. Tadpoles of $P$. minuta differ from that of $P$. cururu by presenting the nostril nearer to eye than to tip of snout (closer to tip of snout in P. cururu), and by the spiracle nearer to snout than to body-tail junction (closer to body-tail junction in P. cururu; Eterovick \& Sazima 1998). The tip of tail is rounded in $P$. minuta, pointed in $P$. cururu, $P$. concavitympanum, $P$. cristiceps, $P$. laticeps, $P$. renalis, and $P$. tupinamba. The size of eyes in $P$. minuta (eye diameter [ED] 9-10\% body length [BL]) is similar to that of some species with palpebral appendages (P. laticeps and P. renalis; ED up to 9.5\% BL), P. schirchi (ED 10\% BL), P. avelinoi (ED 9\% $\mathrm{BL}$ ), smaller than that of $P$. palustris (ED 11\% BL) and species related to the P. cristiceps group (P. cristiceps, $P$. concavitympanum, and P. cururu; ED larger than $12 \% \mathrm{BL}$ ), and larger than P. appendiculata, P. boiei, P. moehringi, and $P$. tupinamba (ED < 9\% BL). Second tooth row interrupted in P. minuta, continuous in P. appendiculata and $P$. tupinamba.

Geographic distribution. Proceratophrys minuta is known from two localities in the northern sector of the Espinhaço mountain range (fig. 5), both included in the Chapada Diamantina ecoregion (Velloso et al. 2002). The 
Chapada Diamantina ecoregion is comprised in the Caatinga Morphoclimatic Domain, characterized by vegetation morphologically and physiologically adapted to semiarid conditions (Ab'Sáber 1977). At both localities, elevations range from approximately $800 \mathrm{~m}$ to $1300 \mathrm{~m}$. The topography is characterized by mountainous terrain, with deep valleys and steep cliffs, and is classified as extremely unstable with medium slopes ranging from $30^{\circ}$ to $45^{\circ}$, except for the tops. According to the Köppen classification, the climate is of the semi-arid BSwh type, rainy in the summer and dry during winter. The rainy period is from October to April, and the wettest months are from November to January. Because of the high elevations, minimum temperatures reach less than $14^{\circ} \mathrm{C}$ in winter whereas in the surrounding areas are up to $20^{\circ} \mathrm{C}$. Such characteristics are reflected in the vegetation cover, which consists of seasonal semi-deciduous forests and environments of campo rupestre (rocky mountain fields), which contrasts with lowland areas surrounding these mountains (up to ca. $500 \mathrm{~m}$ a.s.l.) that are characterized by shallow soils with caatinga vegetation (Ab'Sáber 2003). An extended description of the study area of the Parque Estadual das Sete Passagens can be assessed in Xavier and Napoli (2011).
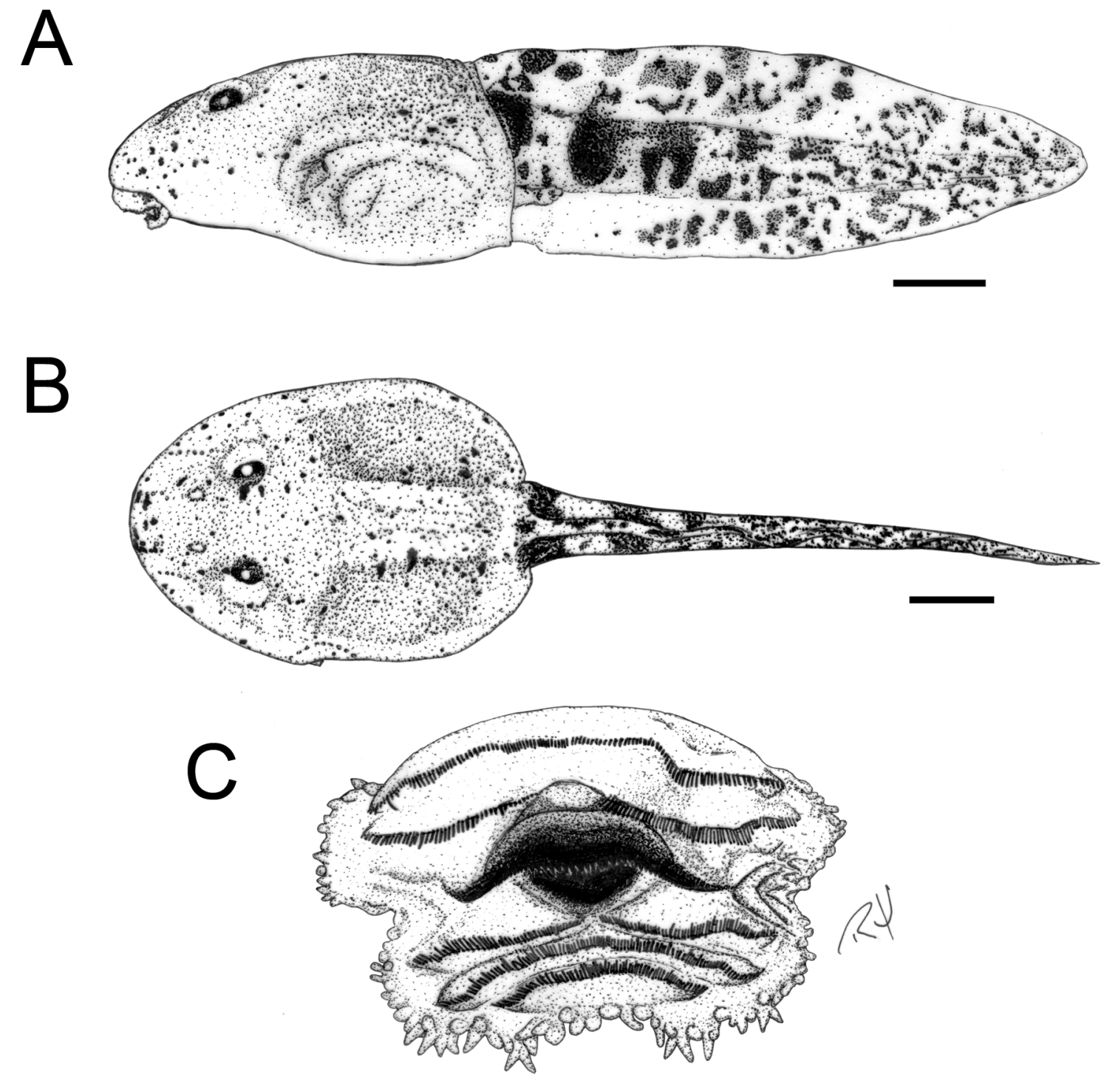

FIGURE 4. Tadpole of Proceratophrys minuta, UFBA 10758, stage 35. (A) Lateral and (B) dorsal views, and (C) oral disc. Horizontal lines equal $3.0 \mathrm{~mm}$. 


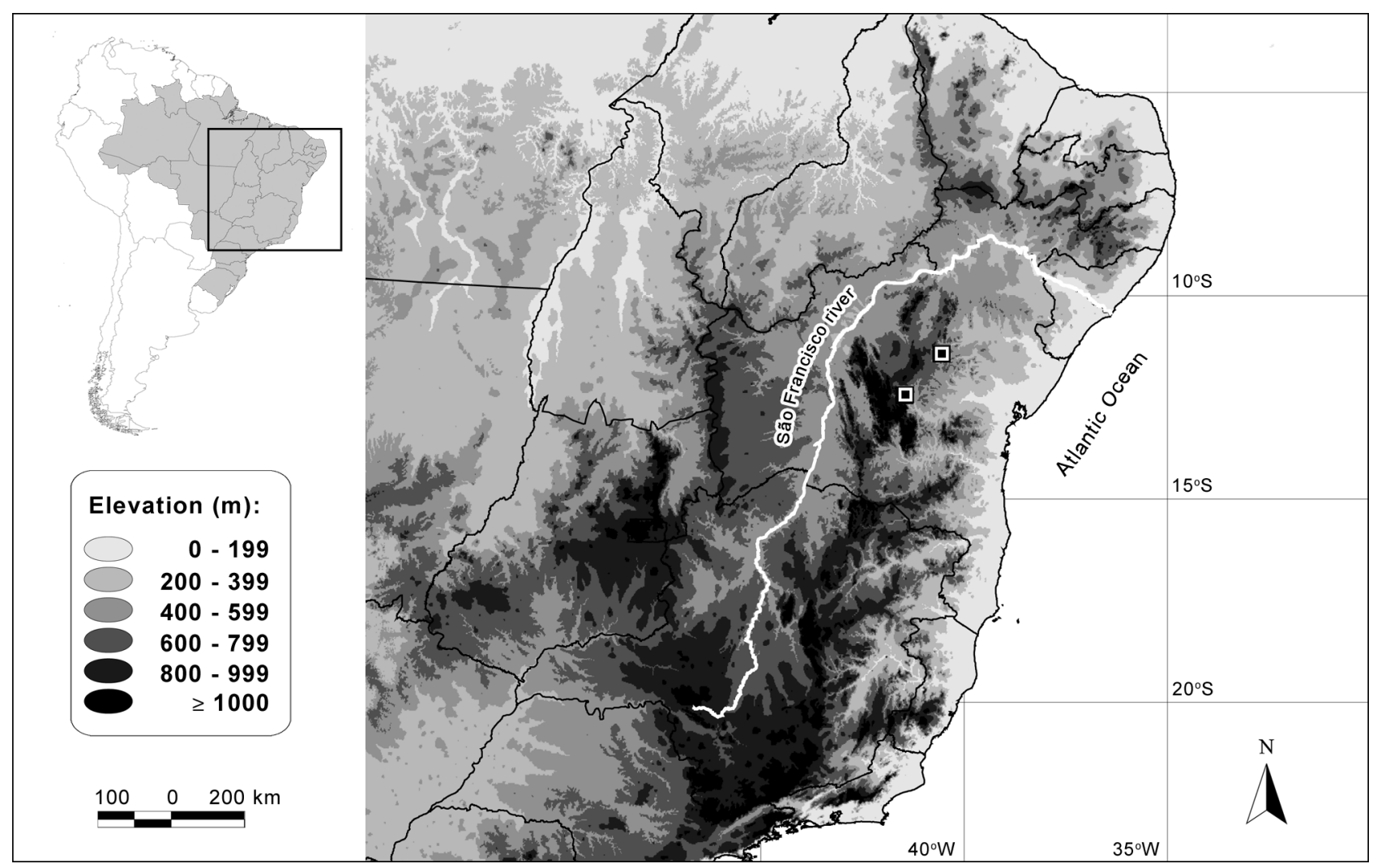

FIGURE 5. Geographic distribution of Proceratophrys minuta on topographic map.

TABLE 2. Descriptive statistics of tadpoles of Proceratophrys minuta ( $\mathrm{n}=9$, stages 31-38) from the Parque Estadual das Sete Passagens, Municipality of Miguel Calmon, State of Bahia, Brazil. Mean = arithmetic mean; SD = standard deviation. Measurements are in millimeters.

Stages (Gosner 1960)

$3134 \quad 36(\mathrm{n}=2) \quad 38(\mathrm{n}=4)$

\begin{tabular}{|c|c|c|c|c|c|c|c|c|c|c|c|}
\hline & & & & Mean & SD & Min & Max & Mean & SD & Min & Max \\
\hline TL & 31.4 & 29.7 & 33.1 & 35.7 & 0.5 & 35.3 & 36.1 & 35.1 & 0.9 & 33.8 & 35.7 \\
\hline BL & 12.3 & 11.5 & 13.8 & 14.3 & 0.1 & 14.2 & 14.4 & 14 & 0.3 & 13.7 & 14.4 \\
\hline MBH & 5.7 & 6.4 & 7.4 & 7.0 & 0.7 & 6.5 & 7.4 & 7.5 & 0.6 & 6.7 & 8.0 \\
\hline MBW & 7.8 & 9.0 & 10.3 & 10.0 & 0.1 & 9.3 & 10.7 & 10.1 & 0.8 & 9.3 & 11.1 \\
\hline TAL & 19.2 & 18.1 & 19.3 & 21.4 & 0.7 & 20.9 & 21.8 & 21.0 & 0.9 & 19.8 & 21.7 \\
\hline МТH & 6.2 & 6.2 & 6.7 & 7.5 & 0.3 & 7.3 & 7.7 & 7.3 & 0.4 & 6.7 & 7.6 \\
\hline TMH & 24.0 & 25.0 & 22.0 & 30.0 & 0.0 & 30.0 & 30.0 & 28.0 & 0.8 & 27.0 & 29.0 \\
\hline DFH & 2.4 & 2.6 & 2.7 & 2.8 & 0.2 & 2.7 & 3.0 & 2.8 & 0.2 & 2.6 & 3.0 \\
\hline VFH & 1.5 & 1.6 & 2.0 & 1.7 & 0.2 & 1.5 & 1.9 & 1.9 & 0.2 & 1.5 & 2.1 \\
\hline ED & 1.1 & 1.1 & 1.2 & 1.3 & 0.0 & 1.3 & 1.3 & 1.4 & 0.1 & 1.3 & 1.4 \\
\hline IOD & 3.3 & 3.6 & 3.8 & 4.0 & 0.3 & 3.8 & 4.2 & 4.1 & 0.1 & 4.0 & 4.3 \\
\hline IND & 1.5 & 1.6 & 1.5 & 1.7 & 0.1 & 1.6 & 1.8 & 1.8 & 0.1 & 1.6 & 1.9 \\
\hline ODW & 3.0 & 3.0 & 3.1 & 3.3 & 0.1 & 3.2 & 3.4 & 3.2 & 0.1 & 3.1 & 3.4 \\
\hline ESD & 3.6 & 3.6 & 3.8 & 4.0 & 0.1 & 3.9 & 4.1 & 3.9 & 0.2 & 3.7 & 4.1 \\
\hline END & 1.0 & 1.2 & 1.2 & 1.1 & 0.0 & 1.1 & 1.1 & 1.2 & 0.1 & 1.0 & 1.3 \\
\hline NSD & 2.4 & 2.5 & 2.6 & 2.9 & 0.1 & 2.9 & 3.0 & 2.8 & 0.3 & 2.4 & 3.1 \\
\hline SSD & 6.3 & 6.7 & 7.0 & 7.1 & 0.6 & 6.7 & 7.5 & 7.8 & 0.4 & 7.3 & 8.2 \\
\hline
\end{tabular}




\section{Acknowledgements}

We are grateful to Miguel C. Accioly for the invitation to join the team that formulated the management plan of the Parque Estadual das Sete Passagens (PESP); to Ariane L. Xavier, Camila V. Bastazini, Deise Cruz, Milena Camardelli, Patricia M. Fonseca, Thais A. F. Dória, Herverton Cardona, Marina Bonfim, Natália Menezes, Wilton Fahning, Tasso Meneses, Thiago Filadelfo, and Tiago Jordão for the excellent field assistance; to José M. Pereira (Zélis) for logistical assistance at the PESP. The Secretaria do Meio Ambiente (SEMA), the Instituto Brasileiro do Meio Ambiente e dos Recursos Naturais Renováveis (IBAMA) (Proc. 02006.001462/2006-13 and 02006.002336/ 03-26), and the local administration of the PESP permitted collection of specimens; the Conselho Nacional de Desenvolvimento Científico e Tecnológico (CNPq) for financial support, and for fellowships to C.A.G. Cruz (Proc. 301172/2009-9), M.F. Napoli (Proc. 302542/2008-6), and M.L Del-Grande (Proc. 475020/2004-9)

\section{References}

Ab’Sáber, A.N. (1977) Os domínios morfoclimáticos na América do Sul. Geomorfologia, 52, 1-21.

Ab’Sáber, A.N. (2003) Os domínios de natureza no Brasil - potencialidades paisagísticas. Ateliê Editorial, São Paulo, 159 pp.

Altig, R. (1970) A key to the tadpoles of the continental United States and Canada. Herpetologica, 26, 180-207.

Altig, R. \& Johnston, G.F. (1986) Major characteristics of free-living anuran tadpole. Smithsonian Herpetological Information Service, 67, 1-75.

Altig, R. \& McDiarmid, R.W. (1999) Body plan: development and morphology. In: McDiarmid, R.W. \& Altig, R. (Eds.), Tadpoles. The biology of anuran larvae. University of Chicago and London, Chicago (USA) and London (UK), pp. $24-51$.

Amaro, R.C., Pavan, D. \& Rodrigues, M.T. (2009) On the generic identity of Odontophrynus moratoi Jim \& Caramaschi, 1980 (Anura, Cycloramphidae). Zootaxa, 2071, 61-68.

Ávila, R.W., Kawashita-Ribeiro, R.A. \& Morais, D.H. (2011) A new species of Proceratophrys (Anura: Cycloramphidae) from western Brazil. Zootaxa, 2890, 20-28.

Caramaschi, U. \& Velosa, A. (1997) Stombus precrenulatus Miranda-Ribeiro, 1937, a junior synonym of Proceratophrys schirchi (Miranda-Ribeiro, 1937) (Anura: Leptodactylidae). Copeia, 1997, 629-631.

Cruz, C.A.G. \& Napoli, M.F. (2010) A new species of smooth horned frog, genus Proceratophrys Miranda-Ribeiro (Amphibia: Anura: Cycloramphidae), from the Atlantic Rainforest of eastern Bahia, Brazil. Zootaxa, 2660, 57-67.

Eterovick, P.C. \& Sazima, I. (1998) New species of Proceratophrys (Anura: Leptodactylidae) from southeastern Brazil. Copeia, 1998, 159-164.

Fatorelli, P., Costa, P.N., Laia, R.C., Almeida-Santos, M., Van Sluys, M. \& Rocha, C.F.D. (2010) Description, microhabitat and temporal distribution of the tadpole of Proceratophrys tupinamba Prado and Pombal, 2008. Zootaxa, 2684, 57-62.

Frost, D.R. (2011) Amphibian species of the World: an online reference. Version 5.5 (31 January, 2011). Electronic Database accessible at http://research.amnh.org/vz/herpetology/amphibia/ American Museum of Natural History, New York, USA. Accessed in 21 October 2011.

Giaretta, A.A. \& Sazima, I. (1993) Nova espécie de Proceratophrys Mir. Rib. do sul de Minas Gerais, Brasil (Amphibia, Anura, Leptodactylidae). Revista Brasileira de Biologia, 53, 13-19.

Giaretta, A.A., Bernarde, P.S. \& Kokubum, M.N.C. (2000) A new species of Proceratophrys (Anura: Leptodactylidae) from the Amazon Rain Forest. Journal of Herpetology, 34, 173-178.

Gosner, K.L. (1960) A simplified table for staging anuran embryos and larvae with notes on identification. Herpetologica, 16, 183-190.

Izecksohn, E., Cruz, C.A.G. \& Peixoto, O.L. (1979) Notas sobre o girino de Proceratophrys boiei (Wied) (Amphibia, Anura, Leptodactylidae). Revista Brasileira de Biologia, 39, 233-236.

Izecksohn, E., Cruz, C.A.G. \& Peixoto, O.L. (1998) Sobre Proceratophrys appendiculata e algumas espécies afins (Amphibia; Anura; Leptodactylidae). Revista da Universidade Rural, Série Ciências da Vida, 20, 37-54.

Kwet, A. \& Faivovich, J. (2001) Proceratophrys bigibbosa species group (Anura: Leptodactylidae), with description of a new species. Copeia, 2001, 203-215.

Martins. L.B. \& Giaretta, A.A. (2011) A new species of Proceratophrys Miranda-Ribeiro (Amphibia: Anura: Cycloramphidae) from Central Brazil. Zootaxa, 2880, 41-50.

Mercês, E.A. \& Juncá, F.A. (2010) Girinos de três espécies de Aplastodiscus Lutz, 1950 (Anura - Hylidae) ocorrentes no Estado da Bahia, Brasil. Biota Neotropica, 10, 167-172.

Nascimento F.A.C., Lisboa, B.S., Skuk, G.O. \& de Sá, R.O. (2010) Description of the tadpole of Proceratophrys renalis (Miranda-Ribeiro, 1920) (Anura: Cycloramphidae). South American Journal of Herpetology, 5, 241-248.

Peixoto, O.L. \& Cruz, C.A.G. (1980) Observações sobre a larva de Proceratophrys appendiculata (Günther, 1873) (Amphibia, Anura, Leptodactylidae). Revista Brasileira de Biologia, 40, 491-493.

Peixoto, O.L., Izecksohn, E. \& Cruz, C.A.G. (1981) Notas sobre o girino de Proceratophrys laticeps Izecksohn \& Peixoto (Amphibia, Anura, Leptodactylidae). Revista Brasileira de Biologia, 41, 553-555. 
Peixoto, O.L., Cruz, C.A.G., Izecksohn, E. \& Carvalho-e-Silva, S.P. (1984) Notas sobre o girino de Proceratophrys precrenulata (Amphibia, Anura, Leptodactylidae). Arquivos da Universidade Federal Rural do Rio de Janeiro, 7, 83-86.

Prado, G.M. \& Pombal, J.P. (2008) Espécies de Proceratophrys Miranda-Ribeiro, 1920 com apêndices palpebrais (Anura; Cycloramphidae). Arquivos de Zoologia, 39, 1-85.

Rossa-Feres, D.C. \& Jim, J. (1996) Tadpole of Odontophrynus moratoi (Anura, Leptodactylidae). Journal of Herpetology, 30 , 536-539.

de Sá, R.O. \& Langone, J.A. (2002) The tadpole of Proceratophrys avelinoi (Anura: Leptodactylidae). Journal of Herpetology, 36, 490-494.

Savage, J.M. \& Heyer, W.R. (1997) Digital webbing formulae for anurans: a refinement. Herpetological Review, $28,131$.

Velloso, A.L., Sampaio, E.V.B. \& Pareyn, F.G.C. (2002) Ecorregiões propostas para o Bioma Caatinga. Associação Plantas do Nordeste, Instituto de Conservação Ambiental The Nature Conservancy do Brasil, Recife, 76 pp.

Vieira, W.L.S., Vieira, K.S. \& Santana, G.G. (2007) Description of the tadpoles of Proceratophrys cristiceps (Anura: Cycloramphidae, Odontophrynini). Zootaxa, 1397, 17-24.

Weygoldt, P. \& Peixoto, O.L. (1985) A new species of horned toad (Proceratophrys) from Espírito Santo, Brazil (Amphibia: Salientia: Leptodactylidae). Senckenbergiana Biologica, 66, 1-8.

Xavier, A.L. \& Napoli, M.F. (2011) Contribution of environmental variables to anuran community structure in the Caatinga Domain of Brazil. Phyllomedusa, 10, 45-64.

\section{Appendix 1. Additional species and specimens examined}

Proceratophrys cururu—BRAZIL: State of Minas Gerais: Serra do Cipó (MNRJ 17905, paratype).

Proceratophrys cristiceps-BRAZIL: State of Ceará: Milagres (MNRJ 75156-75157). State of Sergipe: São Cristóvão (MNRJ 50377). State of Bahia: Barreiras (MNRJ 1737, 22367); Feira de Santana (MNRJ 1684, 1747, 2023, 3703, 3752, 3758); Miguel Calmon (MNRJ 7896-7898).

Proceratophrys goyana-BRAZIL: State of Tocantins: Nova Olinda (MNRJ 48137, 66815). State of Goiás: Rio São Miguel (MNRJ 296, 47902, lectotypes); Colinas do Sul (MNRJ 66224-66225, 66527); Campinorte (MNRJ 53096); Serra da Mesa (MNRJ 20209-20212).

Proceratophrys concavitympanum-BRAZIL: State of Pará: Serra dos Carajás, Paravapebas (MNRJ 58854-58855).

Proceratophrys moratoi-BRAZIL: State of São Paulo: Botucatu (MNRJ 15872).

Proceratophrys schirchi-BRAZIL: State of Bahia: Amargosa (UFBA 6427, 7505, 8492); Jussari (MNRJ 26456-26458). State of Minas Gerais: Marliéria (UFV 5401, 5402, 5408, 5735). State of Espírito Santo (MNRJ 56000, 1831). 